\title{
Constructing Competency Model for Yemeni Oil and Gas Operators \& Technicians Based on Training, Assessment, Motivation and the Role of Skilled Pool Experts
}

\section{Ahmed AL-Qadhi}

To Link this Article: http://dx.doi.org/10.6007/IJARBSS/v11-i3/8884

DOI:10.6007/IJARBSS/v11-i3/8884

Received: 01 January 2021, Revised: 27 January 2021, Accepted: 24 February 2021

Published Online: 28 March 2021

In-Text Citation: (AL-Qadhi, 2021)

To Cite this Article: AL-Qadhi, A. (2021). Constructing Competency Model for Yemeni Oil and Gas Operators \& Technicians Based on Training, Assessment, Motivation and the Role of Skilled Pool Experts. International Journal of Academic Research in Business and Social Sciences, 11(3), 1143-1161.

\section{Copyright: @ 2021 The Author(s)}

Published by Human Resource Management Academic Research Society (www.hrmars.com)

This article is published under the Creative Commons Attribution (CC BY 4.0) license. Anyone may reproduce, distribute, translate and create derivative works of this article (for both commercial and non-commercial purposes), subject to full attribution to the original publication and authors. The full terms of this license may be seen at: http://creativecommons.org/licences/by/4.0/legalcode

Vol. 11, No. 3, 2021, Pg. 1143 - 1161

Full Terms \& Conditions of access and use can be found at http://hrmars.com/index.php/pages/detail/publication-ethics 


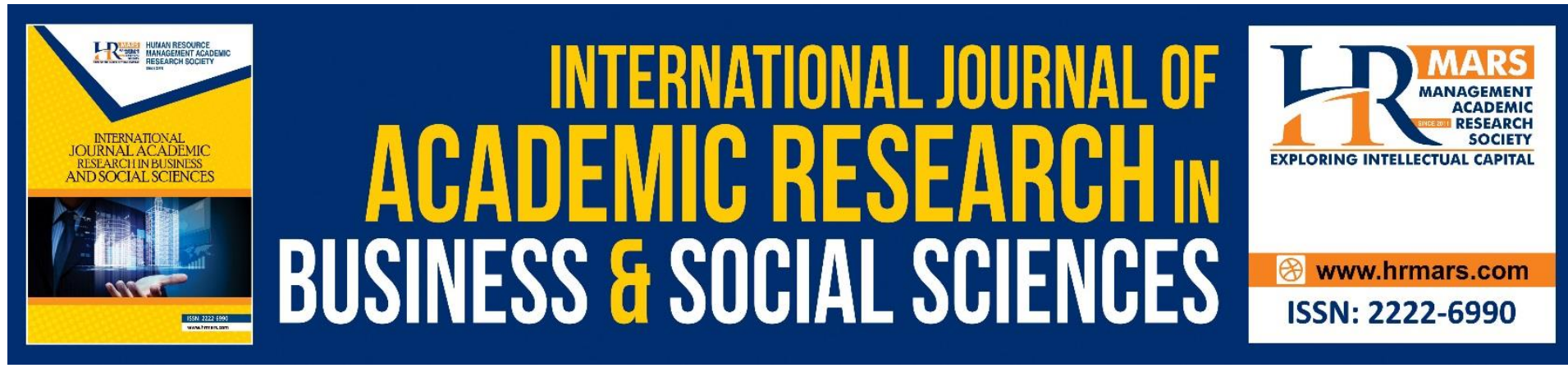

\title{
Constructing Competency Model for Yemeni Oil and Gas Operators \& Technicians Based on Training, Assessment, Motivation and the Role of Skilled Pool Experts
}

\author{
Ahmed AL-Qadhi \\ University Sultan Zainal Abidin, Malaysia
}

\begin{abstract}
The main objective of this study was to develop a competency model and study the relationships of intensive training, quality assessment, motivation, and skill pool expert on the core competencies of workers serving in the oil and gas industry in Yemen to maintain sustainable productivity, development of the country's economy, employees' safety and clean environment in the $O \& G$ production. A preliminary study and questionnaire were used to assess the technical trainees' perceptions in operation, maintenance, and safety of five oil companies in Yemen. The sample was 350 trainees in this study. The data were analyzed by using SPSS software and Structural Equation Modelling (SEM). The result found that intensive training, quality assessment motivation has a significant positive effect on employees' core competence, however, the skill pool expert specifically in line supervisor and coach has a strong effect on employees' core competencies. Multiple linear regression analysis was used to test a hypothesis. This study was conducted in five oil companies and among 350 trainees only. For this reason, the results cannot be generalized to other contexts, where the other companies not interested and implemented conventional training programs, characteristics, and peer support from the work environment, were outside the scope of the study. This study will add value to the efforts of the oil exploration and production board in Yemen, by providing an increased understanding of the factors that create competent technicians based on the competency model
\end{abstract}

Keyword: O\&G Companies, Competency Models, Personal Development Plan, Risk, And Hazard In Petroleum Companies, Structural Equation Model

\section{Introduction}

The issue of the competency of employees and their performance in the petroleum industry is an ongoing concern. Concerning the Oil and Gas (O\&G) industry, they are committed to ensuring that their workforce is knowledgeable and skillful enough to address the issue of competency in executing their tasks and activities in the process of O\&G production. It is becoming increasingly difficult to ignore the importance of the factors influencing the performance of employees in petroleum industries (Connor, 2014). Human Resources (HR) form part of the competence structures of $O \& G$ companies in which the staff engagement 
ensures the protection of all future risks (Wolf \& Pollitt, 2009). The support required by O\&G staff to improve their expertise and abilities will permit them to meet the requirements of the International Human Resources Development Corporation.

This risk may lead to environmental harm, economic loss to businesses, and even humans death. The working staff may take the risk mitigation involved in balancing all potential hazards in the O\&G sector (Morrison, Bachmann, \& Saccomanno, 2017). The staff in the O\&G businesses should be capable to organize appropriate essential abilities in a committed skills framework. The availability of this staff is therefore important in ensuring that both the required knowledge and aptitudes are accurately inserted and upgraded to ensure their safe working environments without sacrificing quality efficiency (Morrison et al., 2017).

There has recently been increased enthusiasm for establishing a skills framework for employees in the field of technology despite the nature of this activity, subjected to high risks (Wolf \& Pollitt, 2009).

The recommendation sent by IHRDC is to broaden the basis of sections that enhance the understanding and build capabilities of staff through the $O \& G$ association. One of the major problems in this sector is to educate new employees about health safety and environment (HSE) so, that they can perform their duties efficiently in line with HSE norms (Al-Awai, Samir, \& Binthabet, 2002a). Similarly, it should achieve the required HR efficiency by improving the workforce's consciousness that falls under the banner of Well Operations Crew Resource Management (WOCRM) and their performance and competency should meet the requirement drawn by the International Association of Oil and Gas Producers (IOGP) (Smith \& Lock, 2015).

Additionally, it is necessary to implement different activities from diverse zones by properly managing them. Therefore, the O\&G management and employee groups in the platform region offshore are capable to carry out operations in a safe manner

The O\&G organizations have the opportunity to improve their existing skills framework through persistent progress in these essential facilities (Al-Awai, Samir, \& Binthabet, 2002b). This should enable the front-line staff of $O \& G$ to meet the basic requirement for the safety of agents to prevent accidents and company disruption in cases where components of the competency framework do not appear (Al-Awai et al., 2002b).

O\&G businesses and their associations should provide advancement in adjusting and modifying the current competency framework. Over the last century, the O\&G industry has rapidly evolved and the interests of skills and academic qualifications have been significantly increased. However, from the perspective of workers and employers, it has been shown that the qualifying skills are vital compared to those of the power companies. The latest sophisticated technology shows that the identification of jobs is different from other classical methods, while skills alone are not informative enough (Figgis \& Standen, 2005).

There should be no major difference between changes in the fundamental section of the competence structure and the procedure for implementing the aspects of different sections of O\&G businesses. According to (van Wieringen, 2019), the O\&G companies are considered to be of international standing with a workable skills framework, fulfilling the O\&G goals. The skillful and well-prepared workforce will benefit the O\&G companies and in the end, will contribute to the success of the entire O\&G business (Abueva, 2011).

These employees' successes and disappointments will have an overall impact on O\&G Company's sustainability in the future, and competent employees contribute mightily to the entire industry, whose successes and failures can have a global effect. 


\section{Competencies in the Oil and Gas Industry in Yemen}

There has been great concern by several organizations concerning the poor competency workforce in the petroleum sector (Rothwell, Graber, \& Graber, 2010). The concern raised includes the disorders of the employee's competencies of the specific work procedure. The other is a rundown in implementing the assignments important to the employee's activity related to the individual employee-specific extraordinary performance.

The recent economic recession that hits the global $O \& G$ industry caused $O \& G$ employers to either be laid off or on the waiting list to resign (Connor, 2014; Ogle, Burley, Magan, Senapati, \& Connor, 2012). This situation has interrupted the current framework of O\&G's competencies to prevent employees from performing.

Over a century of the $O \& G$ industry, there has been a dramatic increase in major accidents that have been occurred in petroleum processing and production. The Occupational Safety and Health Administration (OSHA) and organization managers are keen that their workforce is skilled, knowledgeable, experienced, responsible, and competent to assess the risk and place the right measures for safety, health, and environment. Therefore, the organization should provide intensive training, quality assessment based on the competency model.

Specialized political economy scientist, (Barahim Adnan, Khanbari Khaled, Algodami Amal, Almadhaji Ziad, \& Adris Ahmed, 2018) has stated that local capacity building programs should be implemented in the Yemeni local force, which requires necessary skills and knowledge related to the use of technology in business. (Hakimi, Al-Sufi, Al-Hamadi, \& Al-Sharabi, 2015). According to (Lewis, 2003), many accidents are occurring every day in petroleum companies due to the lack of skills, knowledge, and experience. Nevertheless, the investigation revealed that the operators were the major cause of these accidents, performing jobs in the O\&G sectors (Leveson, 2011).

Thus, the absence of skills in the workforce is the primary cause of these accidents occurring in the O\&G sectors (Andrews, 2011), therefore staying on top of best practices and growing on the job can ensure that an employee will remain valuable to his or her employer.

The lack of a Strategic Facility Training and Facilities Training plan in today's news dealing with Yemeni oil/gas shortcomings lead to the skill lacking, poorly qualified staff, human errors, business disruptions, damage to the environment, and lots of accidents 
Table1. The different causes of accidents occurring in the O\&G sector

\begin{tabular}{|c|c|c|c|}
\hline Accident & Company /date & Cause & Authors \\
\hline $\begin{array}{l}\text { Chemical } \\
\text { explosion }\end{array}$ & Yemen Total, 2008 & $\begin{array}{l}\text { Human Error, ignoring } \\
\text { safety regulation }\end{array}$ & $\begin{array}{l}\text { (Alkhaldi, } \\
\text { Pathirage, } \\
\text { Kulatunga, 2017; } \\
\text { Bhavsar, } \\
\text { Srinivasan, \& } \\
\text { Srinivasan, 2016) }\end{array}$ \\
\hline $\begin{array}{l}\text { Ridan wellhead } \\
\text { blowout }\end{array}$ & Safer Co. 2012 & $\begin{array}{l}\text { Ineffective safety, } \\
\text { management } \\
\text { programs }\end{array}$ & $\begin{array}{l}\text { (Press; Tamers et } \\
\text { al., 2018) }\end{array}$ \\
\hline $\begin{array}{l}\text { LNG storage tank } \\
\text { leaking }\end{array}$ & YLNG, 2011 & $\begin{array}{l}\text { Unsafe act, and } \\
\text { corrosion } \\
\text { effective } \\
\text { identification }\end{array}$ & $\begin{array}{l}\text { (Acciaro, 2014; } \\
\text { Hakimi et al., 2015) }\end{array}$ \\
\hline Power station trips & Aden Refinery, & $\begin{array}{l}\text { Inexperienced } \\
\text { workers, Inadequate } \\
\text { supervision }\end{array}$ & (Newstrom, 2012) \\
\hline $\begin{array}{l}\text { Total shutdown, } \\
\text { instrument air failure }\end{array}$ & Al-Masilah Co, 2007 & $\begin{array}{l}\text { Human } \begin{array}{r}\text { error, } \\
\text { Inadequate } \\
\text { straining }\end{array} \\
\text { traies }\end{array}$ & $\begin{array}{l}\text { (Hakimi, Abdullah, } \\
\text { \& Shalaby, 2012) }\end{array}$ \\
\hline
\end{tabular}

\section{Research Objectives}

To study the factors affecting the core competency of employees in oil and gas companies in Yemen

\section{Theoretical Conceptual Model}

The mapping literature and the industrial model related to the competency model provided the foundation for selection criteria of core competence and demonstrated the essential components in the O\&G competency model based on 2 categories.

The category is based on the competency approach in the literature review.

The category is based on the competency framework of major O\&G companies.

The competency factors outcomes of literature and industries are summarized in Figure 1. The selection of most variables or factors has been made to construct a theoretical, conceptual model and achieve the current study's objectives, with the selection of intensive training, quality assessment, motivation, and skill pool expert in attaining competent operators and technicians. With a specific end goal to consider the components related to the competency-based training, ways have been constructed based on the member's responses to design the competency system and the workplace factors 


\section{Selection Criteria for Competency Components}

\begin{tabular}{|c|c|c|}
\hline & COMPETENCE COMPONENTS & \\
\hline LITERATURE MAPPING & & MAJOR OIL COMPANIES \\
\hline Knowledge, skill (training) & & Development plan \\
\hline Process ability & & Practice with coach \\
\hline Organizational /workforce & & Capability assessment \\
\hline Role base competency & & Management Reporting \\
\hline Competency model design & & Basic training \\
\hline Competency model goals, & & On job training \\
\hline Relevance of contents & & Process Standardization \\
\hline Work environment & & Competency Assurance \\
\hline Training and motivation & & $\begin{array}{l}\text { Training needs analysis and } \\
\text { evaluation }\end{array}$ \\
\hline Person job fit & CORE & Development and delivery of \\
\hline Health and safety, & & instructor-led training \\
\hline Training and development & & $\begin{array}{c}\text { Process safety training } \\
\text { solutions }\end{array}$ \\
\hline Compensation and benefit & & Personnel develop skills \\
\hline Performance appraisal & & Experiential setting \\
\hline Reward and nromotion & & Recruitm ent and selection \\
\hline keward and promotion & & Perform ance Managem ent \\
\hline Flexible scheduling & & Career Mana gement \\
\hline Work environment & & Reward Mana gem ent \\
\hline on job performance & & Technical phase 1,2 \\
\hline & & Organizational objective \\
\hline Mentor support system & & Organizational performance \\
\hline Graduate development & & Experience \\
\hline Quality assurance & & Behavior \\
\hline Management support & & Recognition \\
\hline
\end{tabular}

Figure 1 Selection variables of competency model 
Table 2. Competency Model Comparison in Global O\&G Companies

\begin{tabular}{|c|c|c|c|c|}
\hline Company & $\begin{array}{l}\text { Competency Model } \\
\text { Variables }\end{array}$ & $\begin{array}{l}\text { Training } \\
\text { Support }\end{array}$ & $\begin{array}{l}\text { Performance } \\
\text { Method }\end{array}$ & Author \\
\hline Petro skill & $\begin{array}{l}\text { CM } \\
\text { Tailored competency } \\
\text { map } \\
\text { Gaps define } \\
\text { Development plan } \\
\text { Knowledge and } \\
\text { assessment } \\
\text { Practice with coach } \\
\text { Capability assessment } \\
\text { Management } \\
\text { Reporting }\end{array}$ & $\begin{array}{l}\text { e-Learning } \\
\text { Pilot library } \\
\text { HSE } \\
\text { Unit } \\
\text { operation }\end{array}$ & Assessment1, 2 & $\begin{array}{l}\text { (Matteo, } \\
\text { 2019) }\end{array}$ \\
\hline $\begin{array}{l}\text { Abu -Dhabi } \\
\text { national oil } \\
\text { company } \\
\text { (ADNOC) }\end{array}$ & $\begin{array}{l}\mathrm{CM}-\mathrm{CAMS} \\
\text { Induction of industry } \\
\text { Basic training } \\
\text { On job training } \\
\text { External training } \\
\text { Quality assurance }\end{array}$ & $\begin{array}{l}\text { CBT } \\
\text { computer- } \\
\text { based } \\
\text { training } \\
\text { E-learning, } \\
\text { Quiz, video }\end{array}$ & $\begin{array}{l}\text { Six months of } \\
\text { basic training } \\
\text { Assessment, } \\
\text { criteria } \\
\text { Awareness, } \\
\text { acknowledgment, } \\
\text { skill, and mastery }\end{array}$ & $\begin{array}{l}\text { (Almatroushi, } \\
\text { 2006) }\end{array}$ \\
\hline $\begin{array}{l}\text { International } \\
\text { human } \\
\text { resources } \\
\text { development } \\
\text { corporations } \\
\text { (IHRDC) }\end{array}$ & $\begin{array}{l}\text { Competency } \\
\text { Management } \\
\text { Process } \\
\text { standardization } \\
\text { Competency content } \\
\text { Learning and } \\
\text { development and } \\
\text { Gap analysis and } \\
\text { planning }\end{array}$ & $\begin{array}{l}\text { Software } \\
\text { e-learning }\end{array}$ & $\begin{array}{l}\text { assessment } \\
\text { Individual } \\
\text { competency } \\
\text { profile }\end{array}$ & $\begin{array}{l}\text { (Connor, } \\
\text { 2014) }\end{array}$ \\
\hline Shell & $\begin{array}{l}\text { CM- strategic } \\
\text { competency } \\
\text { management } \\
\text { Competency assurance } \\
\text { include risk, position, } \\
\text { task, role competency } \\
\text { development }\end{array}$ & $\begin{array}{l}\text { Simulator, } \\
\text { e-learning } \\
\text { Short } \\
\text { courses } \\
\text { Video } \\
\text { Drill }\end{array}$ & $\begin{array}{l}\text { Assessing, } \\
\text { Approach } \\
\text { Storing, tracking, } \\
\text { and reporting }\end{array}$ & $\begin{array}{l}\text { (Kedzierski, } \\
\text { 2016) }\end{array}$ \\
\hline Wood Group & $\begin{array}{l}\text { Training, training } \\
\text { simulation, } \\
\text { competence, } \\
\text { assessment }\end{array}$ & 3d simulator & $\begin{array}{l}\text { Assessment } \\
\text { process }\end{array}$ & $\begin{array}{l}\text { (Van De Port, } \\
\text { Wood- } \\
\text { Dauphinee, } \\
\text { Lindeman, \& } \\
\text { Kwakkel, } \\
\text { 2007) }\end{array}$ \\
\hline $\begin{array}{l}\text { PETRONAS } \\
\text { EPDC }\end{array}$ & $\begin{array}{l}\text { PETRONAS } \\
\text { Competency-based } \\
\text { assessment system } \\
\text { (PECAS) }\end{array}$ & $\begin{array}{l}\text { Simulator, } \\
\text { e-learning } \\
\text { Upstream } \\
\text { Downstream }\end{array}$ & $\begin{array}{l}\text { Assessment } \\
\text { process } \\
\text { Internal ass } \\
\text { External ass }\end{array}$ & $\begin{array}{l}\text { (Hashim, } \\
\text { Ahmad, \& } \\
\text { Rohiza, 2010; } \\
\text { McKinley \& }\end{array}$ \\
\hline
\end{tabular}


INTERNATIONAL JOURNAL OF ACADEMIC RESEARCH IN BUSINESS AND SOCIAL SCIENCES Vol. 11, No. 3, 2021, E-ISSN: 2222-6990 @ 2021 HRMARS

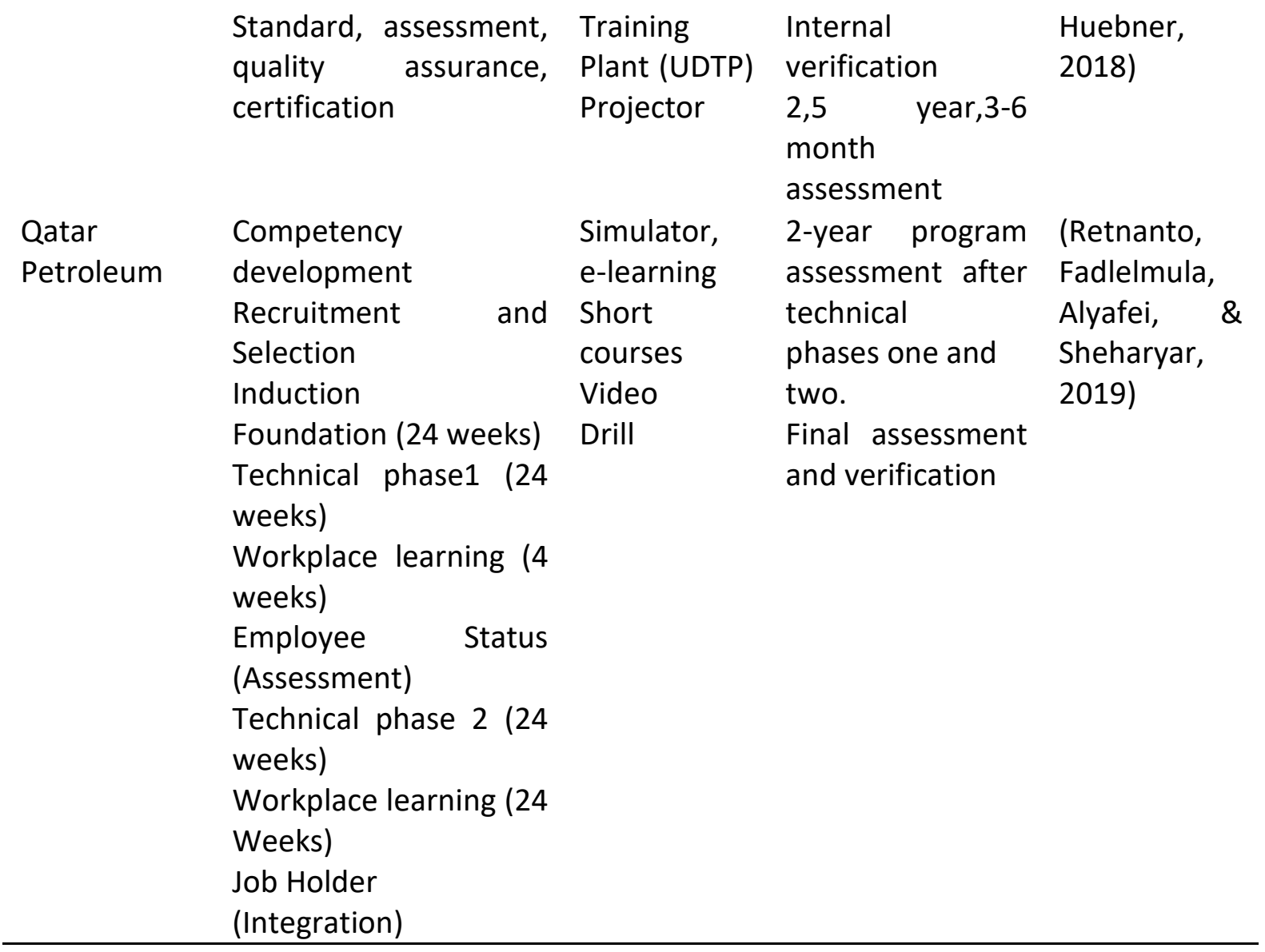




\section{Theoretical Conceptual Competency Model}

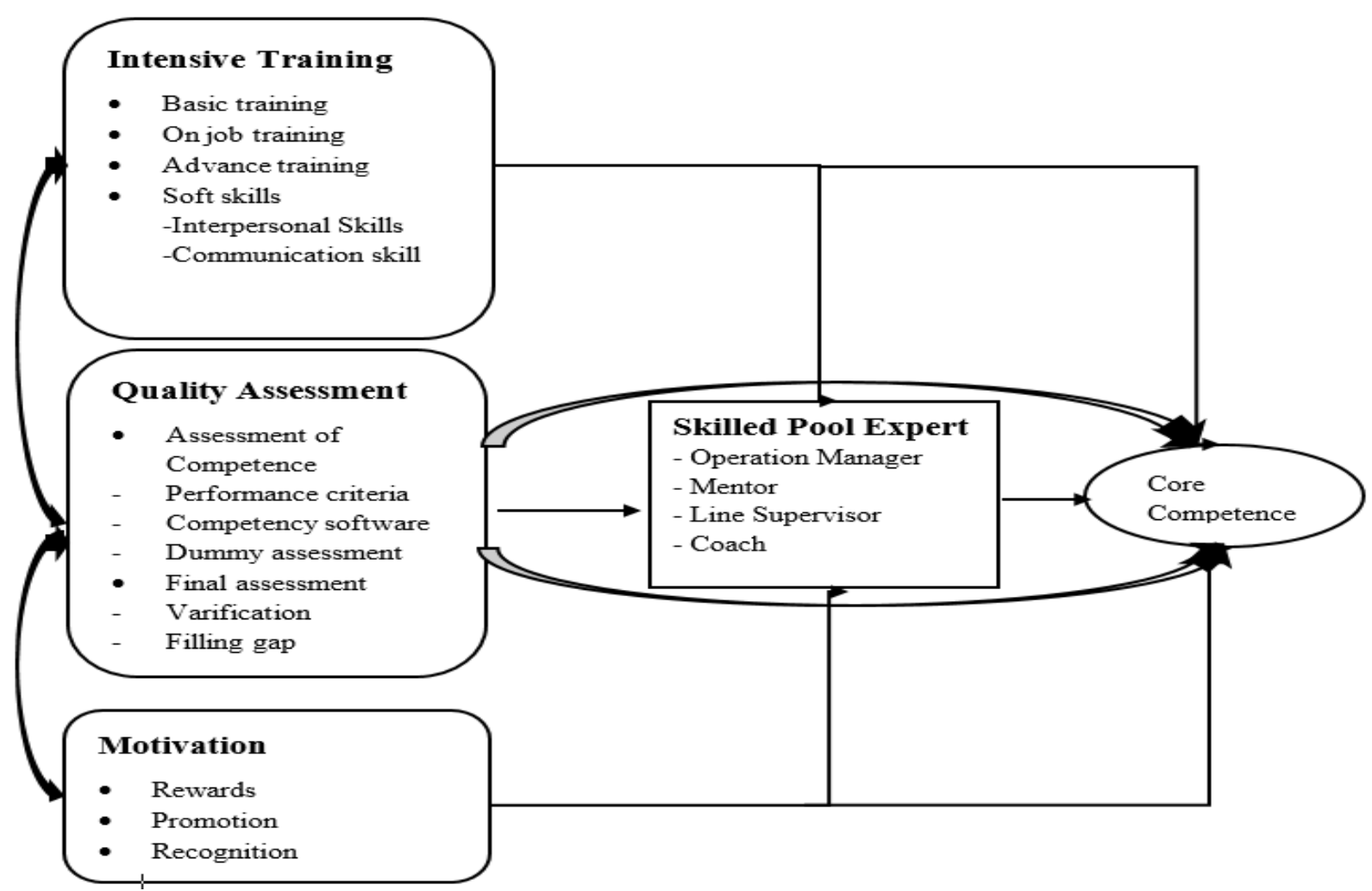

Figure 2. Proposed theoretical competency model

\section{Scope of the Study}

The current study is concentrating on the technical people working in the O\&G industry in Yemen, particularly in the operation, maintenance, and safety division of upstream and downstream facilities. The operators and technicians are intended as they are working in the hazard areas including wellhead operation, separation, refinery, and gas processing (Andersen \& Mostue, 2012). The most recent industrial literature mentioned that the majority of accidents occurred in the high-risk areas, exposed to flammable gases, liquids, high pressure, and temperature due to inadequate competence of technical workers (Andersen \& Mostue, 2012; Lord \& Fenton, 2019)

\section{Research Methodology}

The research methodology consists of research design, sampling design, data collection, and method of analysis. The study's research process has been derived from the design procedure applied by (Shelbourn, Bouchlaghem, Anumba, \& Carrillo, 2007). It is designed to use the preliminary works as an exploratory study before starting the quantitative study's first phase. The central part of the current research will address the quantitative technique to assure the target metric and the statistical analysis of data collected through questionnaires and surveys. 
Figure 3: Research Process Chart

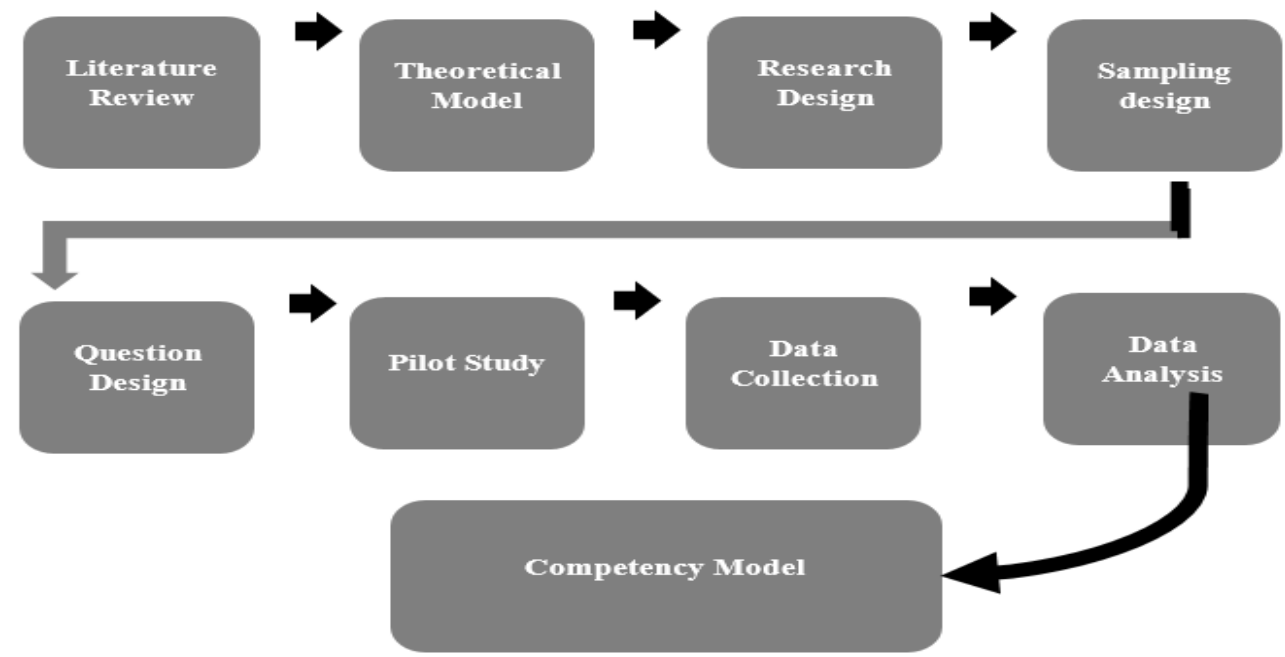

Approximately 3000 technical employees have been targeted in this survey, working in the production, maintenance, and safety sectors of 5 selected O\&G companies in Yemen (z YLNG, SAFER CO, Aden refinery, and Jannah Hunt AL-Masila) (Bloomfield et al., 2016; Thomson, 2018; Yemen) LNG, 2010). According to (Comrey \& Lee, 1992), the sample size is 300 is right, while 1000 is the best. In this study, the sample size is 400 , which is the proper sample size for achieving useful data for analysis.

\section{Findings and Discussion}

This study offers analytical evidence, first, intensive training has a significant positive impact on employees' core competence in the oil and gas industry. Second, quality assessment has no significant impact on employees' core competency. Third, motivation has a strong positive effect on the core competency of workers. Lastly, there was no positive relationship between skill pool expert and core competency of the employees working in the oil and gas industry in Yemen, according to the trainees' perception

The research design is considered reliable when a construct attains at least 0.7 Cronbach alpha value. The current study's results demonstrated adequate validity as the Cronbach alpha values ranged between 0.876 and 0.948 . Thus, the instrument was accurate to proceed with the actual study.

Table 3. The results of Cronbach alpha

\begin{tabular}{lcc}
\hline & Cronbach's Alpha & N of Items \\
\hline Intensive training & 0.916 & 17 \\
Quality assessment & 0.948 & 13 \\
Motivation & 0.876 & 11 \\
Skill pool expert & 0.921 & 13 \\
Core competence & 0.888 & 13 \\
\hline Overall & $\mathbf{0 . 9 4 4}$ & $\mathbf{6 7}$ \\
\hline
\end{tabular}

Relationship with Core Competence.

A regression test was conducted to analyze the impacts of intensive training, quality assessment, motivation, and skill pool expert on core competence. The current study results 
reported that $23.9 \%$ of the variance in the dependent variable (core competence) was explained by four sub-dimension of intensive training, quality assessment, motivation, and skill pool expert. The findings of multiple regression demonstrated that intensive training $[b=0.042, t=0.588, p<0.05]$ and motivation $[b=0.570, t=9.601, p<0.05]$ have significant impacts on core competences. Nevertheless, several dimensions, including quality assessment $[b=-0.055, t=-0.734, p>0.05]$, and skill pool expert $[b=-0.079, t=-1.044, p<0.05]$ did not show any relationship with core competence.

Table 4. Relationship with Core Competence.

\begin{tabular}{|c|c|c|c|c|c|c|}
\hline \multirow[t]{2}{*}{ Model } & & \multicolumn{2}{|c|}{$\begin{array}{l}\text { Unstandardized } \\
\text { Coefficients }\end{array}$} & \multirow{2}{*}{$\begin{array}{c}\text { Standardized } \\
\text { Coefficients } \\
\text { Beta }\end{array}$} & \multirow[t]{2}{*}{$\mathbf{t}$} & \multirow[t]{2}{*}{ Sig. } \\
\hline & & B & $\begin{array}{l}\text { Std. } \\
\text { Error }\end{array}$ & & & \\
\hline \multirow{5}{*}{1} & (Constant) & .854 & .213 & & 4.002 & .000 \\
\hline & Intensive Training & .042 & .072 & .040 & 0.588 & .000 \\
\hline & Quality Assessment & -.055 & .075 & -.050 & -0.734 & .464 \\
\hline & Motivation & .570 & .059 & .498 & 9.601 & .000 \\
\hline & Skill_Pool_Expert & -.079 & .076 & -.072 & -1.044 & .297 \\
\hline
\end{tabular}

a. Dependent Variable: Core Competence

\section{Interpretation of the Results}

The intensive training influences the trainees' core competence in most conventional training programs (Indira, 2008). The intensive training has a significant positive impact on the employees' core competence $(\mathrm{H} 1$, with $\mathrm{p} \mathrm{>0.01)}$. The recent literature stressed the significance of appropriated intensive training in conventional training since its appropriateness strongly influences trainees' core competence working in the oil and gas industry (Alvarez, Salas, \& Garofano, 2004).

On the other side, (Lee \& Ming, 1999) found a positive relationship between quality assessment and employees' core competence in the oil and gas industry. In the same way, (Glassner, 1983) discovered that quality assessment significantly affects employees' core competence. The quality assessment ensures that workers can perform their duties according to companies' guidelines (Davidson \& Al Zadjali, 1999; Fletcher, 1997). Quality assessment is not straightforward since trainees are measured under predefined guidelines established by the business industry.

Trainees are deemed professional, and thus assessors ought to ensure that they can perform the job independently without supervisor assistance (Davidson \& Al Zadjali, 1999; Fletcher, 1997; Novia \& Fernandes, 2014). The assessor's activities are therefore critical since they judge the evidence offered by the trainees to decide whether they are competent or not.

The assessors ought to check candidates' performance while performing their job, which is a part of the evidence (Almatroushi, 2006; A. Matroushi et al., 2008). Assessing trainees' expertise and knowledge under the competency model enables the training program to be more effective from the trainees' viewpoint. A study by (Praslova, 2010) reported that quality assessment could be effectively used to assess the efficacy of conventional training programs 
and the efficiency of competency models. However, in the current survey, the participants did not support the hypothesis that quality assessment in training programs influences the core competencies $(H 2, p=$ programs' efficacy.

In contrast, the trainers' motivation during the training program has had a positive impact on the core competency of the workers according to the trainees' perception in this survey $(\mathrm{H} 3$, with $p<0.01$ ). The trainers should identify different types of motivations required for employees' core competencies at organizational and job levels (Mukherjee, 2011). This will enable businesses to compete effectively with their contenders, providing them a strategic edge (Hamel \& Prahalad, 1990). According to Mukherjee (2011), motivations should apply to the trainees' objectives, so they become competent and skilled workers (Holton III, Bates, \& Ruona, 2000).

However, this does not apply to the competency model, where both the content and resources contribute to the trainees' performance

Finally, the skill pool experts is the factor that influences the core competence of employees in the oil and gas industry (Le Deist \& Winterton, 2005). However, this study found that there is no relationship between skill pool experts and the core competence of employees according to the trainees' perspective ( $\mathrm{H} 4$, with $\mathrm{p}=0.297)$.

The study's findings confirm that intensive training and motivation influenced all the employees' competency activities $(\mathrm{H} 1, \mathrm{H} 2)$. The explanation is that in executing the training program in a company, the trainers should ensure that the contents of the training are clear, indisputable, rational, simple, and applicable to the tasks of the workers (Lucia \& Lepsinger, 1999; Mukherjee, 2011; Whiddett \& Hollyforde, 2003; Whiddett \& Hollyforte, 1999).

In doing so, supervisors, trainers, experts, and advisors will offer trainees the best guidance to the trainees and consolidate their goals and idea of what the professional trainees desire (Lucia \& Lepsinger, 1999).

The trainers and supervisors may execute the best training programs needed for the trainees' core competencies in their works (Lucia \& Lepsinger, 1999). Trainers should be capable of becoming great mediators. They also effectively evaluate trainees, helping them become top performers, where the primary purpose was to ensure the worker is skilled in performing the risk duty in a safe manner

The above-mentioned discussion demonstrates how significant were the intensive training and motivations in the core competencies of employees in the oil and gas industry (Almatroushi, 2006; Dordan, 2014; Leuro \& Kruger, 2012; H. A. Matroushi, Jabeen, \& All, 2018).

\section{Explanations for Non-Findings}

In conventional training programs, the trainer's engagement is a significant element, influencing the trainees' core competency (Baldwin \& Magjuka, 1997; Fishbein \& Stasson, 1990; Noe, Hollenbeck, Gerhart, \& Wright, 2017). The trainees' transition of training is prevented due to the lack of trainers' assistance (Lim \& Morris, 2006; Martin, 2010). However, trainers' assistance does not affect the potential core competency of employees. As the trainees indicated, the trainers are overwhelmed by the work and do not have enough time to check the trainees' progress. Trainees recommended that they have multiple trainers, so the other trainer will be available for their help if one is busy. The predicted result in this research is the positive impact of intensive training on employees' core competence. The 
trainees presented the explanation that the trainer has a limited period due to his/her other duties.

Suppose the trainer did not give the trainees proper training, why they still expect greater core competency from the trainees. Various other reasons could be asserted for this outcome. The recent literature indicates that certain factors can motivate trainees to pursue a self-directed learning process, such as support from colleagues, willingness to learning, and consciousness (Boyer, Edmondson, Artis, \& Fleming, 2014).

Although the impact of colleagues' input on a core competency does not shape the current study's scope, the initial explanation has been identified from the trainees' input. In conventional training programs, assistance from trainers helps execute the latest acquired skills on the job and modifies the behavior of trainees at work (Bates, Kauffeld, \& Holton, 2007; Colquitt, LePine, \& Noe, 2000; Homklin, Takahashi, \& Techakanont, 2013; Tracey \& Tews, 2005).

The members who finished the training program will instruct their colleagues currently on the course when the trainer is busy. The second explanation is the high rate of self-efficacy of the research trainees. The trainees' feedback affirmed that their training programs' progress came through their obligation and inputs and approached the learning experience. Selfefficacy is the conviction of trainees that they can perform work competently (Bandura, 1986). Trainees with strong self-efficacy are more proficient as they had better understand the impact of training.

Moreover, they respond positively to improving their attitudes once they return to work (Switzer, Nagy, \& Mullins, 2005). According to (Hudson, 1999), self-efficacy is a conscience and cannot be forced by someone else. Self-efficacy does not closely associate with training (Millar, Gitsham, Bozer, Sarros, \& Santora, 2013; Wakkee, Elfring, \& Monaghan, 2010), but it can be improved by training (Joyce \& Showers, 1981). The literature shows that trainees are responsible for the training program's development (Leuro \& Kruger, 2012). The trainer is a mediator only, not a problem solver, and the more the trainees pursue their things at work, the more they will teach (Gallwey, Hanzelik, \& Horton, 2009).

The trainers in the oil and gas industry under investigation seem to have understood adult learning concepts and sought to help their trainees in learning. It is expressed in the trainees' complaints that their trainers did not give them sufficient time. According to (Grow, 1991), the role of trainers changed accordingly to the phase of learning. The third possibility can be the motivation of trainees. It has appeared from the literature that businesses typically concentrate on motivation as it influences trainees' core competency (Bell \& Ford, 2007; Clark, Dobbins, \& Ladd, 1993; Klein, Noe, \& Wang, 2006; Nease, 2000; Seyler, Holton III, Bates, Burnett, \& Carvalho, 1998). Training motivation influences the interactions between the training program and the core competence of the employees. Training characteristics that influence training motivation include training layout, significance, and quality of the contents to the trainees' job requirements. A reward is a decent instance of training design features, which influence trainees' training motivation (Whitehill \& McDonald, 1993).

The relevance of conventional training toward trainees' demands would enhance the trainees' proficiency, resulting in training motivation and transmission (Clark et al., 1993; Nikandrou, Brinia, \& Bereri, 2009). Another element, which influences the motivation of 
trainees, is the quality of training for their work demands (Noe et al., 2017). The last factor that influences the training motivation is the quality of the training required for trainees' demands. This element comprises three prospects from the trainees. First, the extrinsic motivation factors refer to the trainees' expectancies after completing a training program, including increased wages, promotion, or recognition. Second, motivation factors refer to the trainees' expectations that the training program was influencing trainees' competencies.

Thirdly, the training program's expectations will be successful, and the targets will be effectively achieved. This would influence trainees' motivation for learning, such as the effectiveness of the training program and the impressions of the trainees (Tsai \& Tai, 2003). It will not be comfortable asking trainees to pass their acquired expertise in the training without motivation. Therefore, the relationship between self-efficacy and pass training is facilitated by learning and transition motivations (Wen \& Lin, 2014). The competency model fulfills trainees' requirements for acquiring the required knowledge and skills to conduct their works and training for even further tasks. This fulfills the intrinsic motivation factors. In extrinsic motivation, trainees undergo a training program to get promotions and salary adjustments by finishing each evaluation(A. Matroushi et al., 2008). After completing the training program, trainees will be considered competent workers and perform the duties independently (Almatroushi, 2006).

The above explanations illustrate why trainees are encouraged to pursue their training with trainers' assistance. Similarly, some previous studies have demonstrated that focusing on training goals and rewards enhances self-efficacy and strengthens trainees' desire for learning (Wen \& Lin, 2014). The trainees' response to training suggests that motivation influences trainees' core competency (Baldwin \& Magjuka, 1997; Bell \& Ford, 2007; CannonBowers, Salas, Tannenbaum, \& Mathieu, 1995). As competency models rely on extrinsic and intrinsic motivation factors, resulting in a positive response from trainees to the competency model, irrespective of limited training.

\section{Conclusion}

In the oil and gas sector, the need for competent employees continues to be perceived. The implementation of competency-based models is a tool for developing competent workers. This study suggested that specific goals, intensive training, motivation, and skill pool experts ought to achieve a successful competency model and competent employees. The study also recommended studying the self-efficacy impacts of trainees on core competence in term of a developed competency model, other domains recommend conducting extensive research to study the impacts of line supervisor on the trainee's core competence in the event of precommissioning, and commissioning the plant, plant troubleshooting and an emergency status

\section{References}

Abueva, J. (2011). The Power of Training: The importance of competency in the oil \& gas industry. Retrieved from HART ENERGY: http://blogs. epmag. com/guests/2011/01/12/the-power-of-training-the-importance-of-competency-inthe-oil-gas-industry.

Acciaro, M. (2014). Real option analysis for environmental compliance: LNG and emission control areas. Transportation Research Part D: Transport and Environment, 28, 41-50. doi: https://doi.org/10.1016/j.trd.2013.12.007 
Al-Awai, S., Samir, O., \& Binthabet, H. A. (2002a). ADMA-OPCO Operational Approach for Competency Assurance. Paper presented at the Abu Dhabi International Petroleum Exhibition and Conference.

Al-Awai, S., Samir, O., \& Binthabet, H. A. (2002b). ADMA-OPCO Operational Approach for Competency Assurance. Paper presented at the Abu Dhabi International Petroleum Exhibition and Conference.

Alkhaldi, M., Pathirage, C., \& Kulatunga, U. (2017). The role of human error in accidents within oil and gas industry in Bahrain. Paper presented at the 13th International Postgraduate Research Conference (IPGRC): conference proceedings.

Almatroushi, S. R. (2006). The Road to a Competent and Motivated Workforce. Paper presented at the Abu Dhabi International Petroleum Exhibition and Conference.

Alvarez, K., Salas, E., \& Garofano, C. M. (2004). An integrated model of training evaluation and effectiveness. Human resource development Review, 3(4), 385-416.

Andersen, S., \& Mostue, B. A. (2012). Risk analysis and risk management approaches applied to the petroleum industry and their applicability to IO concepts. Safety Science, 50(10), 2010-2019. doi: https://doi.org/10.1016/j.ssci.2011.07.016

Andrews, A. (2011). Why Competency-based Talent Management. Lexonis Limited; https://onepetro.org/search-results?page $=1 \& q=$ Why\%20Competencybased\%20Talent\%20Management., 62(Society of Petroleum Engineers (SPE)), 40-44. doi: https://doi.org/10.2118/118184-MS

Baldwin, T. T., \& Magjuka, R. J. (1997). Training as an organizational episode: Pretraining influences on trainee motivation. Improving training effectiveness in work organizations, 3, 99-127.

Bandura, A. (1986). Social foundations of thought and action. Englewood Cliffs, NJ, 1986, 2328.

Barahim Adnan, A., Khanbari Khaled, M., Algodami Amal, F., Almadhaji Ziad, A., \& Adris Ahmed, M. (2018). Slope Stability Assessment and Landslide Susceptibility Map Production of Wadi Dhahr Area, Northwest of Sana'a, Yemen. Sultan Qaboos University Journal for Science [SQUJS], 23(2), 120-136.

Bates, R., Kauffeld, S., \& Holton, E. F. (2007). Examining the factor structure and predictive ability of the German-version of the Learning Transfer Systems Inventory. Journal of European Industrial Training.

Bell, B. S., \& Ford, J. K. (2007). Reactions to skill assessment: The forgotten factor in explaining motivation to learn. Human Resource Development Quarterly, 18(1), 33-62.

Bhavsar, P., Srinivasan, B., \& Srinivasan, R. (2016). Pupillometry based real-time monitoring of operator's cognitive workload to prevent human error during abnormal situations. Industrial \& Engineering Chemistry Research, 55(12), 3372-3382.

Bloomfield, S. F., Rook, G. A., Scott, E. A., Shanahan, F., Stanwell-Smith, R., \& Turner, P. (2016). Time to abandon the hygiene hypothesis: new perspectives on allergic disease, the human microbiome, infectious disease prevention and the role of targeted hygiene. Perspectives in public health, 136(4), 213-224.

Boyer, S. L., Edmondson, D. R., Artis, A. B., \& Fleming, D. (2014). Self-directed learning: A tool for lifelong learning. Journal of Marketing Education, 36(1), 20-32.

Cannon-Bowers, J. A., Salas, E., Tannenbaum, S. I., \& Mathieu, J. E. (1995). Toward theoretically based principles of training effectiveness: A model and initial empirical investigation. Military Psychology, 7(3), 141-164. 
Clark, C. S., Dobbins, G. H., \& Ladd, R. T. (1993). Exploratory field study of training motivation: Infiluence of involvement, credibility, and transfer climate. Group \& Organization Management, 18(3), 292-307.

Colquitt, J., LePine, J., \& Noe, R. (2000). Trainee attributes and attitudes revisited: A metaanalysis of research on training motivation. Journal of Applied Psychology, 85(5), 678707.

Comrey, A., \& Lee, H. (1992). Interpretation and application of factor analytic results. Comrey AL, Lee HB. A first course in factor analysis, 2, 1992.

Connor, J. (2014). Evolution of the nature and application of competence in the learning and development of oil and gas industry personnel. Paper presented at the IPTC, International Petroleum Technology Conference, Kuala Lumpur, Malaysia, .

Davidson, I. A., \& Al Zadjali, I. (1999). Developing competence-based learning in Oman's Drilling and well services sector. Paper presented at the SPE/IADC Middle East Drilling Technology Conference.

Dordan, J. P. (2014). Talent attraction and management of Competencies in challenging Oil and Gas environment. Paper presented at the Abu Dhabi International Petroleum Exhibition and Conference.

Figgis, J., \& Standen, A. (2005). Training skilled workers: Lessons from the oil and gas industry (N. C. f. V. E. R. A. 311 Ed.): NCVER,National Centre for Vocational Education Research https://ncver.edu.au/research-and-statistics/publications/all-publications/training-skilledworkers-lessons-from-the-oil-and-gas-industry.

Fishbein, M., \& Stasson, M. (1990). The Role of Desires, Self-Predictions, and Perceived Control in the Prediction of Training Session Attendance 1. Journal of Applied Social Psychology, 20(3), 173-198.

Fletcher, S. (1997). Analysing competence: tools and techniques for analysing jobs, roles and functions: Kogan Page Publishers.

Gallwey, W. T., Hanzelik, E., \& Horton, J. (2009). The inner game of stress: Outsmart life's challenges and fulfill your potential: Random House.

Glassner, B. M. (1983). Discovering Audience/Inventing Purpose: A Case Study of Revision in a Cooperative Writing Workshop.

Grow, G. O. (1991). Teaching learners to be self-directed. Adult education quarterly, 41(3), 125-149.

Hakimi, M. H., Abdullah, W. H., \& Shalaby, M. R. (2012). Molecular composition and organic petrographic characterization of Madbi source rocks from the Kharir Oilfield of the Masila Basin (Yemen): palaeoenvironmental and maturity interpretation. Arabian Journal of Geosciences, 5(4), 817-831. doi: https://doi.org/10.1007/s12517-011-02894

Hakimi, M. H., Al-Sufi, S. A., Al-Hamadi, S., \& Al-Sharabi, S. A. (2015). Petrophysical analysis of early cretaceous Saar carbonates from Sharyoof oilfield in the Masila Basin, eastern Yemen, and their impact on reservoir properties and quality. Arabian Journal of Geosciences, 8(12), 11307-11319.

Hamel, G., \& Prahalad, C. K. (1990). The core competence of the corporation. Harvard business review, 68(3), 79-91.

Hashim, A. S., Ahmad, W. F. W., \& Rohiza, A. (2010). A study of design principles and requirements for the m-learning application development. Paper presented at the 2010 International Conference on User Science and Engineering (i-USEr). 
Holton III, E. F., Bates, R. A., \& Ruona, W. E. (2000). Development of a generalized learning transfer system inventory. Human Resource Development Quarterly, 11(4), 333-360.

Homklin, T., Takahashi, Y., \& Techakanont, K. (2013). Effects of individual and work environment characteristics on training effectiveness: Evidence from skill certification system for automotive industry in Thailand. International Business Research, 6(12), 1.

Hudson, F. M. (1999). The handbook of coaching: A comprehensive resource guide for managers, executives, consultants, and human resource professionals: Jossey-Bass San Francisco.

Indira, A. (2008). Evaluation of Training Programs for Rural Development. Journal of Applied Quantitative Methods, 3(2), 139-150.

Joyce, B. R., \& Showers, B. (1981). Transfer of training: The contribution of "coaching". Journal of Education, 163(2), 163-172.

Kedzierski, B. A. (2016). Royal Dutch Shell's Journey to Strategic Competence Management. Journal of Petroleum Technology, 68(01), 46-51. doi: https://doi.org/10.2118/01160046-JPT

Klein, H. J., Noe, R. A., \& Wang, C. (2006). Motivation to learn and course outcomes: The impact of delivery mode, learning goal orientation, and perceived barriers and enablers. Personnel psychology, 59(3), 665-702.

Le Deist, F. D., \& Winterton, J. (2005). What is competence? Human resource development international, 8(1), 27-46.

Lee, S. H., \& Ming, J. A. (1999). Effective reaction evaluation in evaluating training programs. Purposes and dimension classification. Performance Improvement, 38(8), 32-39.

Leuro, J., \& Kruger, T. (2012). Evolving a Business-driven Competency and Employee Development Program to Deliver Superior Business Results and Satisfy Industry Regulations. Paper presented at the SPE Annual Technical Conference and Exhibition.

Leveson, N. G. (2011). Applying systems thinking to analyze and learn from events. Safety Science, 49(1), 55-64. doi: https://doi.org/10.1016/j.ssci.2009.12.021

Lewis, M. A. (2003). Analysing organisational competence: implications for the management of operations. International Journal of Operations \& Production Management.

Lim, D. H., \& Morris, M. L. (2006). Influence of trainee characteristics, instructional satisfaction, and organizational climate on perceived learning and training transfer. Human Resource Development Quarterly, 17(1), 85-115.

Lord, J., \& Fenton, A. (2019). The right to disconnect from the workplace. Croner-i.

Lucia, A. D., \& Lepsinger, R. (1999). Competency Models: Pinpointing critical success factors in organizations. San Francisco: lossey-Bass/Pfeffer.

Martin, H. J. (2010). Improving training impact through effective follow-up: techniques and their application. Journal of Management Development.

Matroushi, A., Rashed, S., Kochanczyk, R., Baba-Ali, F., Al Shekali, K., Verkoelen, J., \& Dupuis, J. (2008). Management Information and Lessons Learned from the Successful Implementation of a Competence Assurance Process in a Complex Environment. Paper presented at the Abu Dhabi International Petroleum Exhibition and Conference.

Matroushi, H. A., Jabeen, F., \& All, S. A. (2018). Prioritising the factors promoting innovation in Emirati female-owned SMEs: AHP approach. International Journal of Entrepreneurship and Innovation Management, 22(3), 220-250.

Matteo, A. (2019). Use of Ontologies and Business Process Management Systems to Measure the "Knowledge Fit" of an Organisation. Budapesti Corvinus Egyetem. 
McKinley, T., \& Huebner, C. (2018). Extractive Industries and Consumption Linkages to Enhance Industrialisation.

Millar, C. C., Gitsham, M., Bozer, G., Sarros, J. C., \& Santora, J. C. (2013). The role of coachee characteristics in executive coaching for effective sustainability. Journal of Management Development.

Morrison, A., Bachmann, C., \& Saccomanno, F. (2017). Generalized Cost Functions of Crude Oil Pipeline Shipments in Canada. Paper presented at the Canadian Transportation Research Forum (CTRF) 52nd Annual Conference, Winnipeg, MB, Canada.

Mukherjee, S. (2011). Competency mapping for superior results: Tata McGraw-Hill Education. Nease, A. A. (2000). Do motives matter? An examination of reasons for attending training and their influence on training effectiveness. https://scholarship.rice.edu/handle/1911/19539.

Newstrom, J. (2012). Supervision: Managing for results (Edition: 10 ed.). https://www.mhprofessional.com/9780078023170-usa-supervision-managing-forresults: McGraw-Hill Higher Education.

Nikandrou, I., Brinia, V., \& Bereri, E. (2009). Trainee perceptions of training transfer: an empirical analysis. Journal of European Industrial Training.

Noe, R. A., Hollenbeck, J. R., Gerhart, B., \& Wright, P. M. (2017). Human resource management: Gaining a competitive advantage: McGraw-Hill Education New York, NY.

Novia, M., \& Fernandes, M. (2014). Using technical competence to drive high-grade safety performance. Paper presented at the SPE International Conference on Health, Safety, and Environment.

Ogle, K. C., Burley, S. D., Magan, T., Senapati, N. K., \& Connor, J. (2012). Building technical excellence: E\&P competency development in India. Paper presented at the IPTC 2012: International Petroleum Technology Conference.

Praslova, L. (2010). Adaptation of Kirkpatrick's four level model of training criteria to assessment of learning outcomes and program evaluation in higher education. Educational assessment, evaluation and accountability, 22(3), 215-225. doi: 10.1002/he.294. Press, Y. October 20, 2012.

Retnanto, A., Fadlelmula, M., Alyafei, N., \& Sheharyar, A. (2019). Active Student Engagement in Learning-Using Virtual Reality Technology to Develop Professional Skills for Petroleum Engineering Education. Paper presented at the SPE Annual Technical Conference and Exhibition.

Rothwell, W. J., Graber, J. M., \& Graber, J. M. (2010). Competency-based training basics: American Society for Training and Development; https://www.td.org/.

Seyler, D. L., Holton III, E. F., Bates, R. A., Burnett, M. F., \& Carvalho, M. A. (1998). Factors affecting motivation to transfer training. International Journal of Training and development, 2(1), 16-16.

Shelbourn, M., Bouchlaghem, N., Anumba, C., \& Carrillo, P. (2007). Planning and implementation of effective collaboration in construction projects. Construction Innovation.

Smith, P., \& Lock, G. (2015). The Challenges Faced and the Successes Achieved in Delivering Well Operations Crew Resource Management in a Multi-Cultural Offshore Environment (Russian). Paper presented at the SPE Annual Caspian Technical Conference \& Exhibition. 
Switzer, K. C., Nagy, M. S., \& Mullins, M. E. (2005). The influence of training reputation, managerial support, and self-efficacy on pre-training motivation and perceived training transfer. Applied HRM Research, 10(1), 21-34.

Tamers, S. L., Goetzel, R., Kelly, K. M., Luckhaupt, S., Nigam, J., Pronk, N. P., . . B Bushnell, T. (2018). Research methodologies for Total Worker Health ${ }^{\circledR}$ : Proceedings from a workshop. Journal of Occupational and Environmental Medicine, 60(11), 968.

Thomson, R. N. (2018). A Self-Administered Parent Training Intervention for Building SocialEmotional Competence among Low-Income Preschoolers: A Non-Concurrent MultipleBaseline Design across Three Cases: Michigan State University.

Tracey, J. B., \& Tews, M. J. (2005). Construct validity of a general training climate scale. Organizational research methods, 8(4), 353-374.

Tsai, W. C., \& Tai, W. T. (2003). Perceived importance as a mediator of the relationship between training assignment and training motivation. Personnel review.

Van De Port, I. G., Wood-Dauphinee, S., Lindeman, E., \& Kwakkel, G. (2007). Effects of exercise training programs on walking competency after stroke: a systematic review. American journal of physical medicine \& rehabilitation, 86(11), 935-951. doi: doi: 10.1097/PHM.0b013e31802ee464

van Wieringen, J. (2019). Extending Global Mobility Programs Throughout the K-Group. Paper presented at the SPE Kuwait Oil \& Gas Show and Conference.

Wakkee, I., Elfring, T., \& Monaghan, S. (2010). Creating entrepreneurial employees in traditional service sectors. International Entrepreneurship and Management Journal, 6(1), 1-21.

Wen, M. L.-Y., \& Lin, D. Y.-C. (2014). Trainees' characteristics in training transfer: The relationship among self-efficacy, motivation to learn, motivation to transfer and training transfer. International Journal of Human Resource Studies, 4(1), 114.

Whiddett, S., \& Hollyforde, S. (2003). A practical guide to competencies: how to enhance individual and organisational performance: CIPD Publishing.

Whiddett, S., \& Hollyforte, S. (1999). The competencies handbook. Career Development International.

Whitehill, B. V., \& McDonald, B. A. (1993). Improving learning persistence of military personnel by enhancing motivation in a technical trainiing program. Simulation \& Gaming, 24(3), 294-313.

Wolf, C. O., \& Pollitt, M. G. (2009). The welfare implications of oil privatization: a cost-benefit analysis of Norway's statoil.

Yemen, L. Co. (2010), Yemen LNG commences production from 2nd train ahead of schedule, hence doubling LNG exports to its international markets: Yemen LNG Co: April. 